\title{
O recurso à autoridade dos clássicos e o retrato do adversário como estratégias discursivas na Apologia contra Rufino, de Jerônimo
}

\author{
LUÍS CARLOS LIMA CARPINETTI \\ Universidade Federal de Juiz de Fora
}

RESUMO: Este artigo trata de dois procedimentos literários que encontramos no texto de São Jerônimo, a Apologia contra Rufino, a saber, o recurso à erudição clássica para construir uma imagem favorável de si mesmo e, por outro lado, construir com os recursos retóricos próprios uma imagem desfavorável e pejorativa do adversário.

PALAVRAS-CHAVE: estilo polêmico; citação; erudição clássica; procedimentos retóricos.

\section{Introdução}

A obra Apologia contra Rufino é um campo em que abundam as polêmicas acesas que ocorreram no seio do cristianismo romano no século IV, época em que viveu São Jerônimo, doutor e santo da Igreja Católica, monge na cidade palestina de Belém, epistológrafo, exegeta, tradutor, polemista e hagiógrafo de notável inteligência e brilho.

Nosso trabalho de tese tem por meta resgatar o aspecto polêmico do texto jeronimiano, a partir do estudo do texto da Apologia contra Rufino. Neste artigo trabalharemos sobre duas estratégias discursivas que encontramos no texto: o recurso à autoridade dos clássicos e o retrato do adversário, como etapa de abordagem dos recursos lingüísticos e literários do estilo polêmico na obra citada.

Polêmico vem do grego polšmikon, adjetivo que traz em sua formação a noção de guerra, combate. Ao adotarmos a categoria de estratégia discursiva, estamos falando, ao utilizarmos o termo estratégia, de um elemento afím à noção de guerra e de combate, já que estratégia é um elemento essencial a qualquer combate, mesmo que seja discursivo. Em Jerônimo, podemos depreender um modelo antigo do panfletário, aquele que busca defender e lutar pela verdade da fé cristã, pela ortodoxia e contra a heresia e que, nas suas relações pessoais com Rufino, busca purificar os meandros obscurecidos por "calúnias" e "acusações" falsas, que condenam o ex-amigo Jerônimo à vala comum da heresia origeniana, 
tema de acesos debates na época. Jerônimo diz no texto que é forçado a defender-se publicamente e por escrito - esta defesa constitui o texto da Apologia, em resposta a uma Apologia contra São Jerônimo, de Rufino - para isentar-se de ser considerado hereticamente um origeniano. O próprio discurso está carregado de metáforas que trazem em si o imaginário do combate com a enumeração de armas ou apetrechos bélicos tais como iacula uenenata (projéteis envenenados), tela (dardos), sagittae (flechas), hastae (lanças), scutum (escudo oval e convexo), clipeus (escudo em forma de telha de cumeeira).

O conjunto da obra em questão compreende três livros, sendo os dois primeiros livros endereçados a Pamáquio e Marcela como sequeência às publicações por Rufino primeiramente, depois por Jerônimo, da tradução latina do Perì Archôn, de Orígenes, a partir do grego, episódios que marcam publicamente a dissidência dos ex-amigos e o recrudescimento de posições quanto às doutrinas de Orígenes. Tais doutrinas sustentam o subordinacionismo do Filho e do Espírito Santo ao Pai; a queda das almas em corpos etéreos, aéreos, ou mais espessos como os corpos carnais dos homens, por causa de sua negligência; a redenção e salvação do diabo; a ressurreição dos corpos em vez da carne. Estas teses não estão em conformidade com a Sagrada Escritura. A interpretação alegórica que lhes dá origem não permite ver com clareza o ensinamento da Escritura, pois mobiliza interpretações infinitas para cada texto. Assim, este método de exegese faz o sentido do texto explodir. Tal método de exegese levantava na época muitas suspeitas de heresia, e os debates em torno de Orígenes seguiam-se naturalmente às suspeitas, dois séculos após a morte do mestre alexandrino. As traduções do Perì Archôn refletem as posições diferenciadas de seus autores. Rufino mostra no texto de Orígenes uma visão católica, enquanto Jerônimo denuncia o herético de Orígenes numa tradução que revela cruamente os erros doutrinais, as heresias, enfim, tudo o que Rufino havia encoberto, segundo o testemunho do texto da Apologia contra Rufino, já que esta tradução de Jerônimo que desmascarava o falseamento pela tradução rufiniana do verdadeiro teor do texto de Orígenes foi destruída por causa do escândalo que ela provocou no meio eclesiástico. Após os acontecimentos da festa de Pentecostes de 394, época em que eclode a controvérsia origenista, na diocese de Jerusalém, dentre os quais podemos citar a ordenação de Pauliniano, irmão de Jerônimo, pelo bispo chipriota Epifânio de Salamina, em território sob jurisdição do bispo de Jerusalém, o que constituiu uma grave usurpação das prerrogativas episcopais do bispado hierosolimitano; a denúncia pelo bispo Epifânio do origenismo do bispo de Jerusalém, fato que se tornou notório a partir da tradução latina de uma carta de Epifânio ao bispo João de Jerusalém, entre outros eventos, a discussão ganha aspectos sociais e não apenas teológicos, e seguirá por décadas a fío. Retomando a questão dos temas tratados nos dois primeiros livros da Apologia contra Rufino, o tema do origenismo ocupa boa parte desse texto. O primeiro livro trata do conflito dos tradutores quanto ao problema da tradução da obra Peri Archôn que os dois protagonistas (Jerônimo e Rufino) traduzem diferentemente; trata também das doutrinas de Orígenes e das questões de comentários na literatura. O segundo livro contém as refutações à Apologia a Anastásio e ao livro da Adulteração dos livros de Orígenes, além da justificação das traduções bíblicas de Jerônimo.

O terceiro livro da Apologia contra Rufino ou a "Carta de Jerônimo contra Rufino" é uma resposta antecipada da parte de Jerônimo à Apologia contra São Jerônimo, escrita por Rufino, antes que a Apologia de Rufino chegue ao conhecimento de Jerônimo. A carta 
discute métodos de tradução, apresenta notícias sobre personalidades no Oriente e no Ocidente, comenta vários incidentes, justifica a réplica de Jerônimo à tradução por Rufino do Perì Archôn e tece apreciações cristãs como soluções do conflito.

\section{O recurso à autoridade dos clássicos}

Citaremos a seguir uma passagem do primeiro livro da Apologia contra Rufino, obra na qual podemos verificar a imensa cultura clássica profana de Jerônimo, e o modo pelo qual ele se vale deste cabedal para aumentar a sua credibilidade junto ao público leitor e ao seu oponente. Na verdade, Jerônimo faz um duplo movimento: por um lado, um movimento favorável ao extremo à sua imagem pessoal e, por outro lado, um movimento desfavorável à imagem do oponente.

Vejamos agora uma passagem do primeiro livro da Apologia contra Rufino, extraída da edição francesa de Pierre Lardet, seguida de tradução nossa:

(...) Tamen in incertum respondebo, donec ad certa perueniam, et $\alpha \nu \tau \iota \zeta \eta \lambda$ ov meum docebo senex quod puer didici, multa esse genera dictionum et, pro qualitate materiae, non solum sententias, sed et structurarum uerba uariari.

Chrysippus et Antipater inter spineta uersantur. Demosthenes et Aeschines contra se inuicem fulminant. Lysias et lsocrates dulciter fluunt. Mira in singulis diuersitas, sed omnes in suo perfecti sunt. Lege ad Herennium Tullii libros, lege Rhetoricos eius; aut, quia illa sibi dicit inchoata et rudia excidisse de manibus, reuolue tria uolumina De Oratore in quibus introducit eloquentissimos illius temporis oratores, Crassum et Antonium, disputantes, et quartum Oratorem quem iam senex scribit ad Brutum. Tunc intelleges aliter conponi historiam, aliter orationes, aliter dialogos, aliter epistulas, aliter commentarios. Ego in commentariis ad Ephesios sic Origenem et Didymum et Apollinarem secutus sum, qui certe contraria inter se habent dogmata, ut fidei meae non amitterem ueritatem. Commentarii quid operis habent? Alterius dicta edisserunt, quae obscure scripta sunt plano sermone manifestant, multorum sententias replicant, et dicunt: Hunc locum quidam sic edisserunt, alii sic interpretantur, illi sensum suum et intellegentiam his testimoniis et hac nituntur ratione firmare, ut prudens lector, cum diuersas explanationes legerit et multorum uel probanda uel improbanda didicerit, iudicet quid uerius sit et, quasi bonus trapezita, adulterinae monetae pecuniam reprobet. Num diuersae interpretationis et contrariorum inter se sensuum tenebitur reus, qui in uno opere quod edisserit, expositiones posuerit plurimorum? Puto quod puer legeris Aspri in Vergilium ac Sallustium commentarios, Vulcatii in orationes Ciceronis, Victorini in dialogos eius, et in Terentii comoedias praeceptoris mei Donati, aeque in Vergilium, et aliorum in alios, Plautum uidelicet, Lucretium, Flaccum, Persium atque Lucanum. Argue interpretes eorum quare non unam 
explanationem secuti sint, et in eadem re quid uel sibi uel aliis uideatur enumerent.

Praetermitto Graecos, quorum tu iactas scientiam - et, dum peregrina sectaris, paene tui sermonis oblitus es -, ne ueteri prouerbio sus Mineruam docere uidear et in siluam ligna portare. Illud miror quod, Aristarchus nostri temporis, puerilia ista nescieris, quamquam tu, occupatus in sensibus, et ad struendam mihi calumniam cernulus, grammaticorum et oratorum praecepta contempseris, paruipendens $v \pi \varepsilon \rho \beta \alpha \tau \alpha$ post anfractus reddere, asperitatem uitare consonantium, hiulcam fugere dictionem. Ridiculum est debilitati et fracti totius corporis uulnera pauca monstrare. Non eligo quod reprehendam, eligat ipse quo uitio careat. Ne illud quidem socraticum nosse debuerat: Scio quod nescio?

Nauem agere ignarus nauis timet; habrotonum aegro

non audet, nisi qui didicit, dare. Quod medicorum est,

promittunt medici. Tractant fabrilia fabri.

Scribimus indocti doctique poemata passim.

Nisi forte se litteras non didicisse iurabit, quod nos illi et absque iuramento perfacile credimus, uel ad Apostolum confugiet profitentem: Etsi imperitus sermone, non tamen scientia. Ille hebraeis litteris eruditus et ad pedes doctus Gamaliel, quem non erubescit, iam apostolicae dignitatis, magistrum dicere, graecam facundiam contemnebat, uel certe quod nouerat humilitate dissimulabat, ut praedicatio eius non in persuasione uerborum, sed in signorum uirtute consisteret, spernens alienas opes, qui in suis diues erat. Quamquam ad imperitum, et per singulas, instar tui, sententias corruentem, numquam pro tribunali Festus diceret: Insanis, Paule, insanis! Multae te litterae ad insaniam conuertunt. Tu qui in latinis mussitas et testudineo gradu moueris potius quam incedis, uel graece debes scribere ut, apud homines graeci sermonis ignaros, aliena scire uidearis, uel si latina temptaueris, ante audire grammaticum, ferulae manum subtrahere et, inter paruulos $\alpha \theta \eta v o \gamma \varepsilon \rho \omega v$, artem loquendi discere. Quamuis Croesos quis spiret et Darios, litterae marsupium non sequuntur. Sudoris comites sunt, laboris sociae; ieiuniorum, non saturitatis; continentiae, non luxuriae. Demosthenes plus olei quam uini expendisse se dicit, et omnes opifices nocturnis semper uigiliis praeuenisse. Quod ille in una littera fecit exprimenda, ut a cane rho disceret, tu in me criminaris, quare homo ab homine hebraeas litteras didicerim. Inde est quod quidam ineruditae prudentiae remanent, dum nolunt discere quod ignorant, nec Horatium audiunt commonentem:

Cur nescire, prudens praue, quam discere malo?

Loquitur et Sapientia, quam sub nomine Salomonis legimus: In maliuolam animam non introibit sapientia nec habitauit in corpore subdito peccatis. Spiritus enim sanctus eruditionis fugiet dolum et recedet a cogitationibus stultis. Aliud est si, uulgi lectione contenti, doctorum aures despiciunt, et contemnunt illud elogium quo procax imperitia denotatur: 
...Non tu in triuiis, indocte, solebas stridenti miserum stipula disperdere carmen?

Quasi non cirratorum turba Milesiarum in scholis figmenta decantent, et Testamentum Suis Bessorum cachinno membra concutiat, atque inter scurrarum epulas nugae istiusmodi frequententur! Cottidie in plateis fictus hariolus stultorum nates uerberat et obtorto scipione dentes mordentium quatit, et miramur si imperitorum libri lectorem inueniant? (...)

Texto latino que assim traduzimos:

(...) Entretanto, eu responderei generalizadamente, até que chegue a dados precisos, e, velho, eu instruirei meu rival sobre aquilo que aprendi quando criança, que muitos são os gêneros literários e que, segundo a natureza do assunto, variam não somente os pensamentos, mas também a forma das construções. Crisipo e Antípatro passam seu tempo em meio a espinhosas sutilezas. Demóstenes e Ésquino desencadeiam ataques fulminantes um contra o outro. Lísias e Isócrates têm um doce fluir. Admirável diversidade, se considerados separadamente, mas todos são perfeitos, cada um em sua obra, a seu modo. Lê os livros de Cícero a Herênio, lê sua Retórica, ou porque ele diz que estes trabalhos lhe caíram das mãos no estágio de esboço grosseiro, percorre os três volumes do De oratore, nos quais ele introduz uma discussão entre os oradores mais eloquüentes daquele tempo, Crasso e Antônio; e seu quarto tratado, o Orator, que, já em sua velhice, escreve para Brutus. Então entenderás que há um modo de compor a história, um outro para os discursos, um outro para os diálogos, um outro para as cartas, um outro para os comentários.

Quanto a mim, em meus comentários sobre a Epístola aos Efésios, eu segui Orígenes, Dídimo e Apolinário, que certamente têm entre si teses contraditórias, sem abandonar a pureza da minha fé. Qual é o papel dos comentários? Eles desenvolvem o que foi dito por um outro. Os textos que comportam obscuridades, eles os explicitam em uma linguagem clara. Eles reproduzem pontos de vista múltiplos e dizem: alguns desenvolveram esta passagem assim, outros assim a interpretam, alguns se esforçam por apoiar seu sentimento e seu modo de ver sobre tais citações e tal argumentação, de modo que o leitor avisado, depois de ter lido as diversas explicações e ter aprendido quais são as múltiplas opiniões suscetíveis de serem aprovadas ou rejeitadas, poderá julgar o que é mais exato e, como bom cambista, recusar o dinheiro de cunho falsificado.

Vai-se por acaso manter sob acusação de interpretação flutuante e apreciações contraditórias aquele que terá exposto, na extensão de uma só obra, as explicações de vários comentadores? Penso que tu leste em tua infância os comentários de Asper sobre Virgílio e Salústio, de Vulcácio sobre os discursos de Cícero, de Victorino sobre seus diálogos, sobre as comédias de Terêncio os de Donato, meu professor, assim como sobre 
Virgílio e outros sobre outros autores, a saber, Plauto, Lucrécio, Horácio, Pérsio e Lucano. Denuncia seus comentadores por não terem adotado uma linha de interpretação única e por recapitular, sobre o mesmo assunto, seu próprio ponto de vista e os de outros autores.

Eu deixo de lado os gregos que tu te gabas de conhecer - e a frequientação das obras estrangeiras quase te fez esquecer tua própria língua! - para que eu não pareça, segundo o velho provérbio, um porco a instruir Minerva e levar madeira à floresta. O que me espanta é que tu, o Aristarco de nosso tempo, tenhas ignorado essas infantilidades, ainda que tu tenhas podido desprezar os preceitos dos gramáticos e dos oradores, absorvido como estás pelas questões de fundo e inclinado a arquitetar contra mim a calúnia, cuidando pouco de resolver os hipérbatos depois das circunlocuções, de evitar a aspereza das cacofonias, de fugir aos hiatos. É ridículo mostrar algumas feridas de um corpo todo quebrado e fraco. Eu não ressalto tal ponto para criticar; que ele próprio escolha o defeito de que carece. Ele não deveria conhecer, pelo menos, este adágio socrático: "Sei que nada sei"?

"Tem medo de conduzir um navio aquele que não entende de navios. Só ousa administrar o abrótono ao doente aquele que aprendeu a fazêlo. Os médicos se comprometem com aquilo que lhes é próprio. Os operários se ocupam de sua obra. Mas ignorantes e sábios, indistintamente, nós escrevemos poemas!"

A menos que, por acaso, ele jure que não aprendeu as letras! Nós acreditaremos nele muito facilmente, ainda que não jure, ou se refugie na declaração do Apóstolo: "Apesar de ser inábil em matéria de discurso, não o sou em ciência". Paulo, instruído nas letras hebraicas e aos pés de Gamaliel que ele não se envergonha de chamar seu mestre, já revestido da dignidade apostólica, ele desprezava sua facilidade de falar o grego, ou, em sua humildade, dissimulava o que sabia, para que sua pregação não repousasse na persuasão da palavra, mas sobre a força dos signos, desdenhando os recursos alheios, pois era rico de recursos próprios. Aliás, a um incompetente como tu, precipitando-se a cada frase, nunca Festus diria do alto de seu tribunal: "Tu deliras, Paulo, tu deliras! Tua vasta cultura te torna louco."

Tu que, nas letras latinas, murmuras e te moves a passo de tartaruga mais do que avanças, ou deves escrever em grego para que pareças saber as letras estrangeiras, junto aos homens que desconhecem a língua grega, ou então se queres exercitar-te nas letras latinas, ouvir primeiramente 0 professor de gramática, subtrair a mão à palmatória, e em meio aos garotos, discípulo senil de Atená, aprender a arte de falar.

Pode-se representar Creso ou Dario, as letras não seguem a bolsa. As letras são companheiras do suor e do esforço, dos jejuns, não da saciedade; da continência, não da luxúria. Demóstenes diz que gastou mais óleo que vinho, e que superou todos os artesãos em vigílias noturnas. 0 
que ele fez para articular uma só letra - ele aprendeu o rho de um cão - tu te queixas disto a mim que, sendo homem, aprendi de um homem as letras hebraicas. Daí vem que alguns permanecem em um grosseiro bom senso, enquanto não quiserem aprender o que ignoram e não ouvem a Horácio com sua admoestação: "Por que, por falsa vergonha, eu prefiro ignorar a aprender?" A sabedoria que nós lemos sob o nome de Salomão diz também: Em uma alma malévola, a sabedoria não entrará nem habitará em um corpo submetido aos pecados; porque o Espírito Santo que nos instrui fugirá à fraude e distanciar-se-á dos pensamentos tolos." É bem outra coisa se, contentando-se de ser lido pelo vulgo, desdenham os ouvidos das pessoas instruídas e desprezam aquela disposição pela qual se estigmatiza a incompetência atrevida: Não és tu, nas encruzilhadas, ignorante, que tinhas o hábito de arruinar um mísero poema com uma charamela estridente? Como se não fosse uma tropa de cabeças encaracoladas que repetem cantando, nas escolas, as fábulas milésias; e o Testamento do Porco que sacode os membros dos Bessos com um riso incontido, e nos banquetes dos histriões abundam frivolidades dessa espécie. Todo dia, nas praças públicas, um falso adivinho bate nas nádegas dos imbecis e, virando rapidamente seu bastão, sacode os dentes daqueles que mordem nele. E nos admiramos que os livros dos incompetentes encontrem leitor? (término da tradução)

Passamos agora a levantar no texto todos os elementos vinculados à cultura clássica: as alusões a personagens, autores e obras, citações de textos, entre outras coisas que nos dão a exata medida do cabedal do autor que delas se serve.

Os poetas que Jerônimo cita na passagem apresentada, ele os conheceu na escola de Donato, o qual editou uma obra de comentários sobre os sete poetas mencionados. Terêncio e Virgílio eram lidos integralmente; os outros, em trechos selecionados. Jerônimo evoca, em primeiro lugar, Terêncio, dando a entender que este lhe deixou uma recordação duradoura. Também para Virgílio, Donato deve ter feito um texto contínuo. A edição francesa da obra de Donato, feita por Louis Holtz, apresenta Jerônimo como o mais brilhante aluno de Donato.

Os dois provérbios que Jerônimo toma de empréstimo à sátira de Horácio fazem parte de uma corrente grega popular e datam de longa tradição: sus Mineruam docere uideri (parecer um porco a instruir Minerva) e in siluam ligna portare (levar madeira à floresta), empregados aqui com tom irônico, uma vez que Jerônimo insinua que Rufino tem conhecimento superficial da língua grega.

Crisipo e Antípatro são autores estóicos cujas obras chegaram até nós por meio de Cícero (Tusculanae disputationes, De officiis, De finibus bonorum et malorum). Os espinhos ou as espinhosas sutilezas (spinae) é um uso clássico, enquanto que spineta é um uso novo. Em outras passagens, existem referências a Crisipo com os vocábulos acumen, acutus e contorta (seu pensamento tortuoso). Demóstenes e Ésquino, polemistas gregos, opõem-se pela hostilidade (no caso de Demóstenes) e pelo apoio (no caso de Esquino) a Felipe de Macedônia. A alusão aos polemistas gregos é muito oportuna, pois isso torna mais espesso o propósito da obra de Jerônimo, uma vez que os protagonistas em questão, Jerônimo e Rufino, enfrentam-se 
em lados opostos quanto às teses origenistas. É verdade que há elementos complicadores neste embate, como a amizade rompida, as relações entre membros da Igreja etc. e que mereceriam uma atenção especial em outro estudo. Lísias e Isócrates, oradores gregos, são caracterizados por Jerônimo com a imagem do rio que corre, imagem extraída de Quintiliano (Inst. Or.10,1,76s.), que faz contraponto com a imagem do raio fulminante (fulmen contra flumen).

Pelo recurso da antonomásia, tropo que consiste em designar um personagem por um nome comum ou uma perífrase que o caracteriza ou, inversamente, designar um indivíduo pelo personagem do qual ele lembra o caráter típico. A antonomásia aqui lembra Aristarco de Samotrácia, que, por volta de 145 a.C. dirigiu a biblioteca de Alexandria, e cujas recensões, sobretudo as de Homero, fizeram dele o tipo do crítico exigente. "Aristarco de nosso tempo" é outro tratamento irônico que concorre desfavoravelmente ao adversário, visto que Jerônimo lembra os erros do ex-amigo, que corroem a imagem de grande crítico.

Jerônimo cita um fragmento das Epístolas de Horácio (Epist.2,1,114-117), o qual integra um texto sobre vários aspectos da literatura em Roma e na Grécia tais como o tratamento pelo público dos escritores jovens e velhos, a apreciação da novidade, as relações entre os modelos gregos e a literatura produzida em Roma.

Com a citação testudineo gradu Jerônimo insere em seu texto o clima divertido das comédias de Plauto, relaxando a atmosfera séria de sua Apologia, tecida de discursos teológicos e citações da Escritura. A cena evocada é da peça Aulularia, na qual Euclião xinga e agride verbalmente Estáfila, dizendo-lhe que não se meta nos assuntos de seu dono, mencionando o passo de tartaruga de Estáfila. No comentário exegético In Oseam, a imagem da tartaruga, lenta e oprimida pelo próprio peso, corresponde ao pecado da heresia. Ironicamente, Jerônimo evoca a imagem do mestre com a palmatória, ao qual Rufino deveria dirigir-se e aprender a gramática e as letras latinas, sendo a palmatória uma metonímia para 0 aprendizado e o estudo da língua em Roma; no caso de Rufino, ele deveria fazê-lo mesmo na velhice, como discípulo senil de Atená.

Para criar a situação da qual o discípulo deveria distanciar-se para progredir no aprendizado das letras, Jerônimo recorre a duas antonomásias: Creso e Dario. Creso, rei da Lídia, é o tipo do rico soberano, igualmente a mesma situação para o caso de Dario. A riqueza de que estes soberanos são representantes é retomada pelo vocábulo marsupium, termo corrente em Plauto, e também em Jerônimo, atestando a predileção deste pelo comediógrafo latino. Os requisitos para o aprendizado das letras vem em seguida, sempre na rota contrária da saciedade e da luxúria.

As fábulas milésias mencionadas no texto são uma designação genérica do conto licencioso, a partir de uma obra de Aristides de Mileto (séc. II a.C.) adaptada em latim por L. Cornelius Sisenna. Uma obra que contém contos que muito parecem dever às fábulas milésias e que chegou até nós é o Satiricon, de Petrônio. O testamento do porco (Testamentum Grunnii Corocottae Porcelli), farsa grosseira em que um porco deixa em herança seus membros a seus pais e amigos, fornece a Jerônimo a alcunha com a qual designará a Rufino.

Em alguns momentos deste item, como nas antonomásias, nas menções irônicas, nas citações e alusões em geral, percebe-se uma tendência a desqualificar o personagem-alvo das críticas por parte do autor da Apologia contra Rufino. No próximo item, veremos todos 
os procedimentos utilizados no texto para atender a esta finalidade, na construção do retrato do adversário.

\section{O retrato do adversário}

De uso antigo na diatribe cínico-estóica, Jerônimo utiliza em sua Apologia o modelo que ele toma em Cícero, em cuja obra podemos citar dois exemplos: o retrato de Catão no Pro Murena e o retrato de Verres no In Verrem. É comum que encontremos descrições do adversário no sentido de caracterizá-lo de modo pejorativo, com antonomásias, metáforas, ultrajes, ultrajes irổnicos, comparações exageradas, descrições pejorativas, desqualificação irônica, uso de vocabulário vulgar, considerações sobre o estilo do adversário, chiste, palavras caricaturais, expressões proverbiais. Neste item, daremos exemplificações a cada procedimento que compõe o retrato do adversário.

Como antonomásia, podemos citar a ocorrência na passagem apresentada: Aristarchus nostri temporis e reminiscências clássicas quasi religiosus et sanctulus (quando Jerônimo se queixa de ter que se defender com um "escudo" do "punhal" de Rufino o qual se cobria de devoção e santidade), satellites (os guardas ou cúmplices, por meio dos quais Rufino dava a ler ao mundo inteiro os livros que ele compunha contra Jerônimo), cereales et anabasii tui (a menção rememora a solicitude de Ceres em busca de sua filha Prosérpina e aplica a idéia desta solicitude às pessoas que espalhavam nas diversas províncias os "infames" elogios de Rufino a Jerônimo.

Como metáfora, temos na abertura do texto da Apologia contra Rufino, a metáfora de cães aplicada aos inimigos: Didici obici in schola Tyranni, a lingua canum meorum ex inimicis ab ipso, cur Peri Archôn libros in latinum uerterim. (Eu soube que sou acusado na escola de Tirano - no caso Rufino - pela língua de cães de meus inimigos de ter traduzido em latim o Perì Archôn).

Há os ultrajes irônicos que têm sabor ciceroniano. Ao chamar Rufino de "hominem prudentissimum' (c. Ruf. 1, 27), Jerônimo espanta-se que Rufino, em sua "grande perspicácia", não tenha compreendido a técnica da sua explicação. Ironicamente, Jerônimo também o insulta com "uir sapientissimus, Romanae dialecticae caput" (c.Ruf. 3, 27 - o sábio por excelência e o chefe dos dialéticos romanos); "sapientiae columen et norma catonianae seueritatis" (c. Ruf. 1, 13 - cume de sabedoria e norma de severidade catoniana); "inclytus syngrapheus" (c. Ruf. 1,9-ilustre escritor); "homo ueracissimus" (c. Ruf. 3, 10-homem de grande veracidade); "homo seuerissimus" (c. Ruf. 1, 30 - homem de grande severidade); "vetustissimus monachorum, bonus presbyter, imitator Christi, dulcissimus amicus" (c. Ruf. 2, 34 - o mais velho dos monges, bom presbítero, imitador de Cristo, o mais doce amigo)

As palavras de ultrajes que acusam o inimigo de estupidez e de falta de cultura e eloqüência se enquadram em um contexto de querela mais restrito e são utilizadas aqui para desqualificar as teses do adversário. A censura de estupidez aparece em formas variadas, chegando até mesmo a abranger em si a censura de loucura: "syngrapheus agrammatos, procacitatem disertitudinem, et maledicere omnibus bonae conscientiae signum arbitraris" (c. Ruf. 3, 6- tu, o letrado sem letras, que tomas a insolência por bem falar e a maledicência 
generalizada por sinal de boa consciência). Há, entretanto, partes de proposições relativas que se apóiam na fórmula do adversário, em parte, proposições principais que exageram conteúdos negativos do adversário, com alusões e insinuações, que, na classificação de Ilona Opelt (1973) denomina-se Satzschimpwörter, o que, em português, podemos considerar como fragmentos de frase de ultraje. Eis um exemplo: "Sed uolui (condiscipulis tuis, qui tecum non didicerunt litteras) quid per triginta annos in Oriente profeceris" (c. Ruf. 3, 6eu quis mostrar aos teus condiscípulos, que contigo não aprenderam as letras, porque viajaste por trinta anos no Oriente). Outro exemplo: "quid de uno pectoris sterquilinio et odorem rosarum et foetorem profers cadauerum" (c. Ruf. 3, 42 - tu cujo coração como um único monte de esterco exalas ao mesmo tempo o odor das rosas e o fedor dos cadáveres).

A menção de traços de caráter negativos do adversário é um outro meio de atacá-lo, e encontramos com muita frequiência a desqualificação moral como traço deste procedimento, lembrando muitas vezes a linguagem jurídica. Vejamos alguns exemplos: "effrenata audacia" (c. Ruf. 3, 25; Cícero, Catilinárias, 1, 1); "effrenata temeritas" (c. Ruf. 2, 21); "foetor" (c. Ruf. 3, 26); "rabies" (c. Ruf. 3, 19); "apertissimum mendacium" (c. Ruf. 2, 2); "mira tergiversatio" (c. Ruf. 3, 23) etc.

Como desqualificação irônica podemos citar o modo pelo qual Jerônimo se refere à Apologia contra São Jerônimo, à qual nosso autor escreve uma refutação antes de lê-la: "eruditissimi libri" (c. Ruf. 3, 3) e "libri venustate attica" (c. Ruf. 1, 3) ou seja livros eruditíssimos, livros de delicadeza ática.

Como chiste, podemos exemplificar com o fragmento seguinte, sempre com o intuito de desqualificar o adversário: "tantam habes graeci latinique sermonis scientiam, ut Graeci te latinum et Latini te graecum putent" (c. Ruf. 3, 6-tens tanto conhecimento do grego e do latim que os gregos te consideram um latino e os latinos, um grego).

\section{Referências Bibliográficas}

CAVALLERA, Ferdinand. Saint Jerôme, sa vie et son oeuvre. 2 tomos. Louvain: Spicilegium sacrum lovaniense; Paris: Honoré Champion, 1922.

HAGENDAHL, Harald. Latin Fathers and the classics. A study on the apologists, Jerome and other christian writers. Göteborg: Elanders Boktryckeri Aktiebolag, 1958.

JEANJEAN, Benoît. Saint Jérôme et l'hérésie. Paris: Institut d'Études Augustiniennes, 1999.

LARDET, Pierre. L'Apologie de Jérôme contre Rufin. Un commentaire. Leiden; New York; Köln: Brill, 1993.

NAUTIN, Pierre. Origène. Sa vie et son oeuvre. Paris: Beauchesne, 1977.

OLTRAMARE, André. Les origines de la diatribe romaine. Lausanne et Genève, 1926.

OPELT, Ilona. Hieronymus' Streitschriften. Heidelberg: Carl Winter Universitätsverlag, 1973. ORÍGENES. Tratado dos princípios. Trad. da versão latina de Rufino por Marguerite HARL, Gilles DORIVAL et Alain LE BOULLUEC. Paris: Études Augustiniennes, 1976. 
SÃO JERÔNIMO. Apologie contre Rufin. Introduction, texte critique, traduction et index par Pierre Lardet. Paris: Éditions du Cerf, 1983.

TESTARD, Maurice. Saint Jérôme. L'apôtre savant et pauvre du patriciat romain. Paris: Les Belles-Lettres, 1969.

CARPINETTI, Luis Carlos Lima, Le recours à l'autorité des classiques et le portrait de l'adversaire comme stratégies discursives dans l'Apologie contre Rufin, de Jerôme. Classica, São Paulo, v. 15/16, n. 15/16, p. 203-213, 2002/2003.

RÉSUMÉ: Cet article traite deux procédés qu'on trouve dans le texte de l'Apologie contre Rufin, à savoir: le recours à l'érudition classique dans le but de construire une image favorable de soimême et, en même temps, construire avec les ressources rhétoriques propres une image défavorable et péjorative de l'adversaire.

MOTS-CLÉS: style polémique; citation; érudition classique; procédés rhétoriques. 